\title{
Articulated avian remains from the early Oligocene of Poland adds to our understanding of Passerine evolution
}

\author{
Zbigniew M. Bochenski, Teresa Tomek, Krzysztof Wertz, Johannes Happ, \\ Małgorzata Bujoczek, and Ewa Swidnicka
}

\begin{abstract}
In total, less than 50 specimens of the Passeriformes are known from the Paleogene, which contrasts with the fact that now it is the largest and most diverse order of birds. The so far described fossils include only three nearly complete specimens, an articulated wing and legs, and a handful of isolated bones. This paper describes a new species and genus of a passerine bird the size of the extant Parus major, imprinted on a slab and a counter slab of the siliceous clayey shales of the Outer Carpathians in southeastern Poland, and dated to the Rupelian, early Oligocene (ca. 31 m.y.a.). It is one of the very few passerine specimens from the Paleogene with bones in articulation, and thus provides a window into the ancestral osteology of passeriforms, which is characterized by a mosaic of characters typical for extant Oscines and Suboscines. The bird shows a unique manus, with a relatively short carpometacarpus and cleavershaped phalanx proximalis digiti majoris. Besides bones, fragmentary feathers are also imprinted on both slabs.
\end{abstract}

Zbigniew M. Bochenski. Institute of Systematics and Evolution of Animals, Polish Academy of Sciences, Slawkowska 17, 31-016 Krakow, Poland. (corresponding author) bochenski@isez.pan.krakow.pl Teresa Tomek. Institute of Systematics and Evolution of Animals, Polish Academy of Sciences, Slawkowska 17, 31-016 Krakow, Poland. tomek@isez.pan.krakow.pl

Krzysztof Wertz. Institute of Systematics and Evolution of Animals, Polish Academy of Sciences, Slawkowska 17, 31-016 Krakow, Poland. wertz@isez.pan.krakow.pl

Johannes Happ. Department of Palaeontology, Faculty of Earth Sciences, University of Vienna, Vienna, Austria. johanneshapp@yahoo.de

Małgorzata Bujoczek. Department of Forest Biodiversity, Faculty of Forestry, University of Agriculture, al. 29 Listopada 46, 31-425 Krakow, Poland. malgorzata.bujoczek@urk.edu.pl

Ewa Swidnicka. Department of Palaeozoology, Institute of Environmental Biology, Faculty of Biological Sciences, University of Wrocław, Sienkiewicza 21, 50-335 Wrocław, Poland. gama@biol.uni.wroc.pl

http://zoobank.org/DDC682C0-D2BD-44FF-B8F2-E48B940DC7D4

Bochenski, Zbigniew M., Tomek, Teresa, Wertz, Krzysztof, Happ, Johannes, Bujoczek, Małgorzata, and Swidnicka, Ewa. 2018. Articulated avian remains from the early Oligocene of Poland adds to our understanding of Passerine evolution. Palaeontologia Electronica 21.2.32A 1-12. https://doi.org/10.26879/843

palaeo-electronica.org/content/2018/2300-passerine-bird-from-oligocene

Copyright: August 2018 Paleontology Society.

This is an open access article distributed under the terms of Attribution-NonCommercial-ShareAlike 4.0 International (CC BY-NC-SA 4.0), which permits users to copy and redistribute the material in any medium or format, provided it is not used for commercial purposes and the original author and source are credited, with indications if any changes are made.

creativecommons.org/licenses/by-nc-sa/4.0/ 
Keywords: fossil birds; Passeriformes; new species; new genus; Menilite shales; Paleogene

\section{INTRODUCTION}

The fossil remains of possible passerine birds dated to the Eocene were described for the first time about 30 years ago in Australia (Boles, 1995, 1997). The findings stimulated the theory of the Southern Hemisphere origin of Passeriformes based on DNA sequences (Ericson et al., 2002) a theory whose details were later challenged (e.g., Mayr, 2013). Since then, three nearly complete specimens of unresolved affinities within Passeriformes, were described from the early Oligocene deposits in Europe: Wieslochia weissi from Germany (Mayr and Manegold, 2004, 2006a), Jamna szybiaki and Resoviaornis jamrozi - both from Poland (Bochenski et al., 2011, 2013). An early Oligocene passerine of Lubéron, France, has not been described yet (Mayr, 2009). Other, less well-preserved Oligocene passerines, include an articulated wing (Mayr and Manegold, 2006b), several dozen isolated wing bones (Mourer-Chauviré et al., 1989; Manegold, 2008), articulated (fragments of) legs (Bochenski et al., 2014a, 2014b), and two fragments of the tarsometatarsus (MourerChauviré et al., 1989, 2004; Mourer-Chauviré, 2006). In total, less than 50 specimens of passerines are known from the Paleogene; most of them are isolated bones and rather poorly preserved imprints on slabs.

In this paper, we describe two partial wings and shoulder girdle found in southeastern Poland (Figure 1). As it is often the case in Paleogene birds, our specimen shows a mosaic of characters typical of extant Oscines and Suboscines. Since the bones are articulated and come from the same bird, the specimen provides a unique opportunity to learn its set of characters, and therefore adds to our understanding of early passerine birds.

\section{MATERIAL AND METHODS}

The specimen consists of a slab and counterslab (Figure 2), with imprints of avian wing bones and feathers (ISEA AF/WIN2a+b). The skeletal elements are preserved as a mixture of bone imprints and remnants of fossilized bone tissue. Therefore, the outlines of bones are well visible but many small details are not recognizable.

Osteological terminology follows Baumel and Witmer (1993). The dimensions are in millimeters,

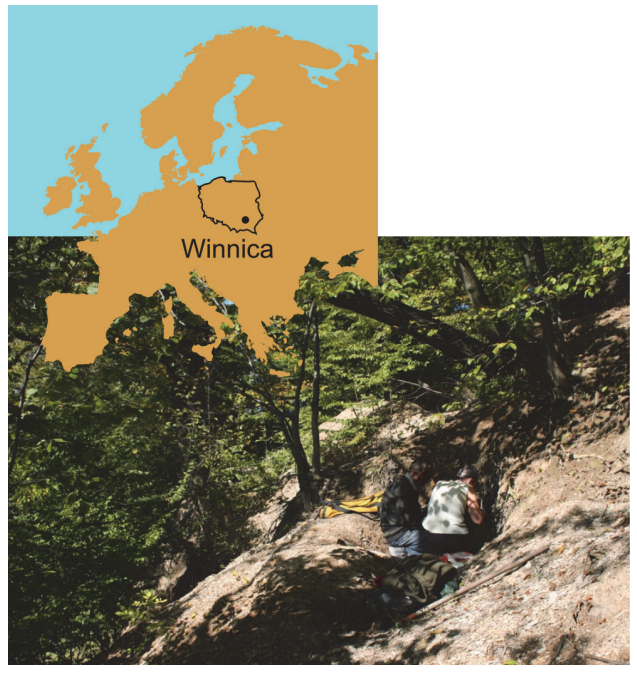

FIGURE 1. Location of the Menilite outcrop at Winnica in southeastern Poland, where the holotype of Winnicavis gorskii gen. et sp. nov. ISEA AF/WIN2a+b was found.

and they represent the greatest length along the longitudinal axis of the bone. The fossil was compared with specimens from the osteological collection of the Institute of Systematics and Evolution of Animals, Polish Academy of Sciences, and with published data on the osteology of extant and fossil Passeriformes (Acanthisittidae, Oscines and Suboscines) as well as extinct Zygodactylidae that are morphologically very similar to passerines (Mayr, 2008,2009 ). The fossiliferous horizon of the type locality, Winnica, has been dated based on the fish assemblage and correlated with the calcareous nannoplankton, in accordance with the correlation given by Kotlarczyk et al. (2006).

Besides conventional photography, the specimen was studied and documented by micro-computed tomography (CT) to visualize possible structures hidden in the matrix. Images were acquired with a SkyScan micro-CT device (model 1173, Bruker) at Department of Palaeontology, University of Vienna, Austria. The processing of the tiff-image stacks was performed with Amira v.5.4.1.

\section{SYSTEMATIC PALAEONTOLOGY}

Class AVES Linnaeus, 1758 Order PASSERIFORMES Linnaeus, 1758 

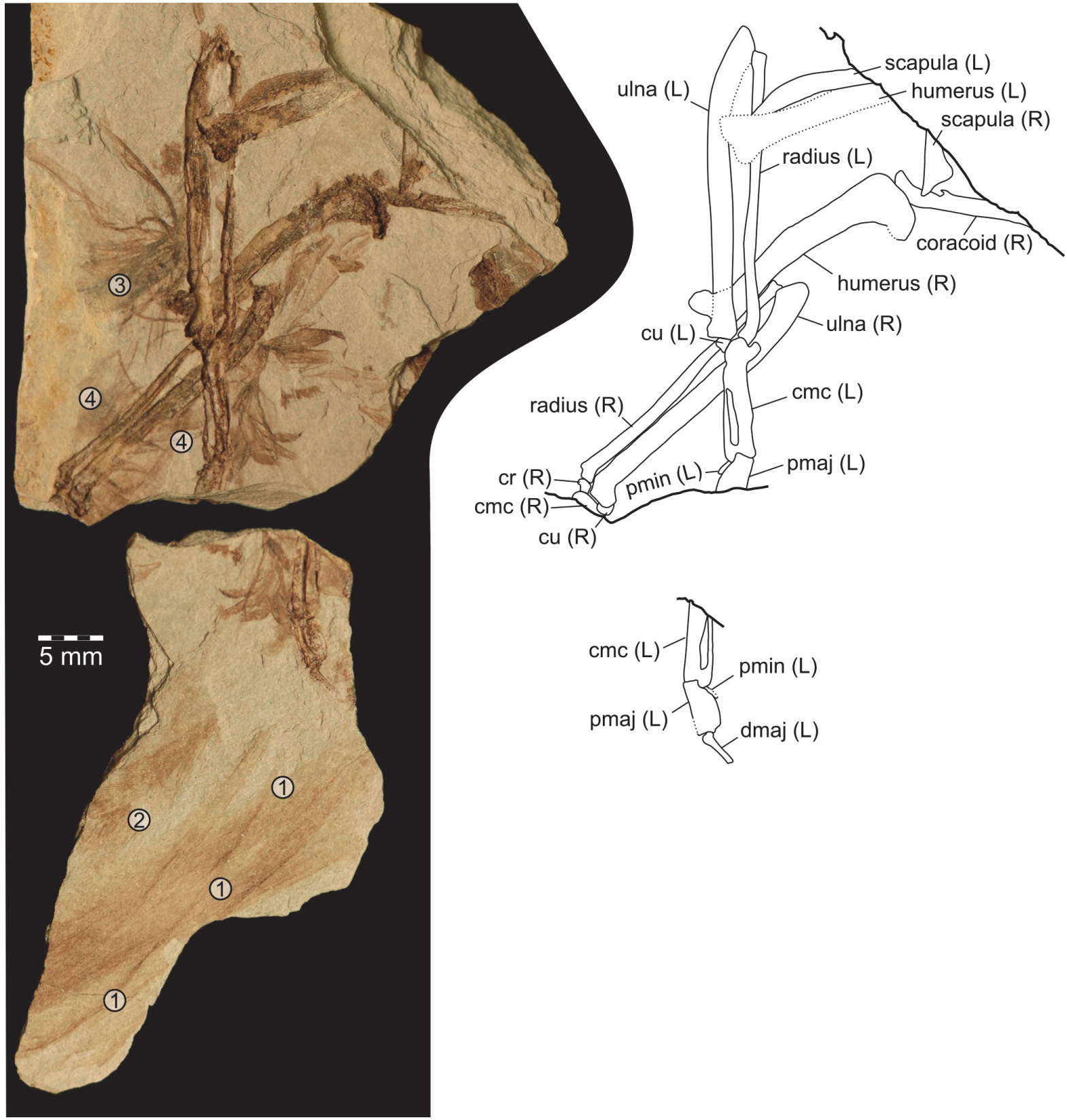

FIGURE 2. Winnicavis gorskii gen. et sp. nov., holotype, specimen ISEA AF/WIN2a+b from Winnica, Poland, early Oligocene (top left - main slab; bottom left - counterslab) and interpretative drawings (right). Left (L) and right (R) elements are indicated. Abbreviations: cmc - carpometacarpus, $\mathrm{cr}$ - os carpi radiale, cu - os carpi ulnare, dmaj - phalanx distalis digiti majoris, pmaj - phalanx proximalis digiti majoris, pmin - phalanx digiti minoris. Numbers in circles on the slabs: 1 - primaries, 2 - secondaries, 3 - underwing coverts, 4 - primary coverts.

Passeriformes incertae sedis Genus WINNICAVIS gen. nov.

\section{zoobank.org/FD341817-A6F6-4C99-8AFA-CFAA6E0F3F44}

Type species. Winnicavis gorskii sp. nov.

Etymology. The genus name is the name of the type locality (Winnica) merged with the Latin word for bird (avis).
Taxonomic remarks. A small passerine which is distinguished from all other non-passerine taxa by the combination of the following characters: 1) the coracoid is long and slender; 2 ) the processus procoracoideus (coracoid) is somewhat enlarged; 3) the tuberculum ventrale (humerus) is well marked; 4) the ulna is slender and longer than the humerus; 5) the olecranon (ulna) is elongated and tapers; 6) 
the cotyla dorsalis (ulna) is proximodistally long and protrudes dorsally; 7 ) there is a shallow saddle between the olecranon and shaft (ulna); 8) the spatium intermetacarpale (carpometacarpus) is long and narrow; 9) the processus intermetacarpalis (carpometacarpus) reaches to the os metacarpale minus; 10) the processus dentiformis (carpometacarpus) is present; 11) the os metacarpale minus (carpometacarpus) protrudes farther distally than the os metacarpale majus.

Differential diagnosis. A small passerine bird, approximately the size of a Great Tit Parus major. from:

Winnicavis gorskii gen. et sp. nov., differs

* All extant Passeriformes in the unique combination of the following characters: coracoid with a rounded and not hooked processus acrocoracoideus and enlarged processus procoracoideus; very stout humerus with broad proximal epiphysis; carpometacarpus proportionally shorter (in relation to the humerus and/or ulna); carpometacarpus with the distal end of the os metacarpale minus protruding only a little farther distally than the os metacarpale majus; and phalanx proximalis digiti majoris is cleaver-shaped and widens considerably cranio-caudally towards its distal end.

* The early Oligocene Wieslochia weissi in: ulna with proximodistally long cotyla dorsalis; and carpometacarpus proportionally shorter (in relation to the humerus and/or ulna).

* The early Oligocene Jamna szybiaki in: coracoid with enlarged processus procoracoideus; humerus with short crista deltopectoralis that merges gradually with the shaft; ulna, in relation to the humerus, clearly longer; carpometacarpus proportionally shorter (in relation to the humerus and/or ulna); carpometacarpus with the distal end of the os metacarpale minus protruding only a little farther distally than the os metacarpale majus; and phalanx proximalis digiti majoris is cleaver-shaped and widens considerably cranio-caudally towards its distal end.

* The early Oligocene Resoviaornis jamrozi in: coracoid with a rounded and not hooked processus acrocoracoideus and enlarged processus procoracoideus; humerus with crista deltopectoralis that merges gradually with the shaft; carpometacarpus proportionally shorter (in relation to the humerus and/or ulna); carpometacarpus with the distal end of the os metacarpale minus protruding only a little farther distally than the os metacarpale majus; and phalanx proximalis digiti majoris is cleaver-shaped and widens considerably cranio-caudally towards its distal end.

* The extinct passerine-like family Zygodactylidae in: ulna, in relation to the humerus, clearly longer; ulna with elongated and tapered olecranon.

* The seemingly similar extinct and extant Coraciiformes in the presence of processus dentiformis (carpometacarpus) and the unique combination of the following characters: coracoid with elongated processus acrocoracoideus and somewhat enlarged but clearly smaller processus procoracoideus; carpometacarpus with processus intermetacarpalis reaching to the os metacarpale minus, and the os metacarpale minus protruding farther distally than the os metacarpale majus.

Winnicavis gorskii gen. et sp. nov. zoobank.org/8C79F1F6-915D-49A3-B844-CD9AEE65C621

Etymology. The species is named after Andrzej Górski (Bielsko-Biala, Poland) who collected the specimen.

Holotype. Two incomplete wings with a shoulder girdle, partially articulated, preserved on two slabs (Figures 2-6), deposited in the Institute of Systematics and Evolution of Animals, Polish Academy of Sciences, Kraków, Poland (ISEA AF/ WIN2a+b).

Type locality and horizon. The specimen was found at Winnica, about $12 \mathrm{~km}$ northwest of Krosno, Podkarpackie Province, southeastern Poland, in marine deposits of the Menilite Shales (Menilite Formation of the Silesian Unit) in the Outer Carpathians. Geographical coordinates of the Winnica exposure: $49^{\circ} 37.94^{\prime} \mathrm{N}, 21^{\circ} 40.44^{\prime} \mathrm{E}$. The outcrop is located on the right high bank of the Jasiołka River. The horizon contains fossil fishes such as Oliganodon budensis (Heckel, 1856), Repropca sabbai (Paucă, 1929) and Palaeogadus simionescui (Simionescu, 1905) belonging to the ichthyofauna of IPM2 Zone (Kotlarczyk et al., 2006), correlated with the calcareous nannoplankton of NP23 zone by Martini (1971) (Berggren et al., 1995; Kotlarczyk et al., 2006), Rupelian, early Oligocene, ca. 31 m.y.a.

Diagnosis. As for the genus.

Measurements. Humerus, 18.6 (right); ulna, 24.5 (left), 23.4 (right); radius, 22.3 (left), 21.4 (right); carpometacarpus, 9.4 (left); phalanx proximalis digiti majoris, 4.3 (left); phalanx distalis digiti majoris, 3.1 (left); phalanx digiti minoris, 1.5 (left).

\section{Description and Comparison}

Coracoid. An imprint of the extremitas omalis of the right coracoid is visible on the main slab. The bone is relatively long and slender as in extant Passeriformes, and embedded with its dorsal side in the matrix. The lateral edge of the shaft is almost straight; it curves laterad at the sternal end. Unlike most modern passerines (Oscines and Suboscines) and the early Oligocene Resoviaornis jamrozi (Bochenski et al., 2013), the tip of the processus acrocoracoideus is not hooked but rounded (Figure 3.1). This condition resembles that in 


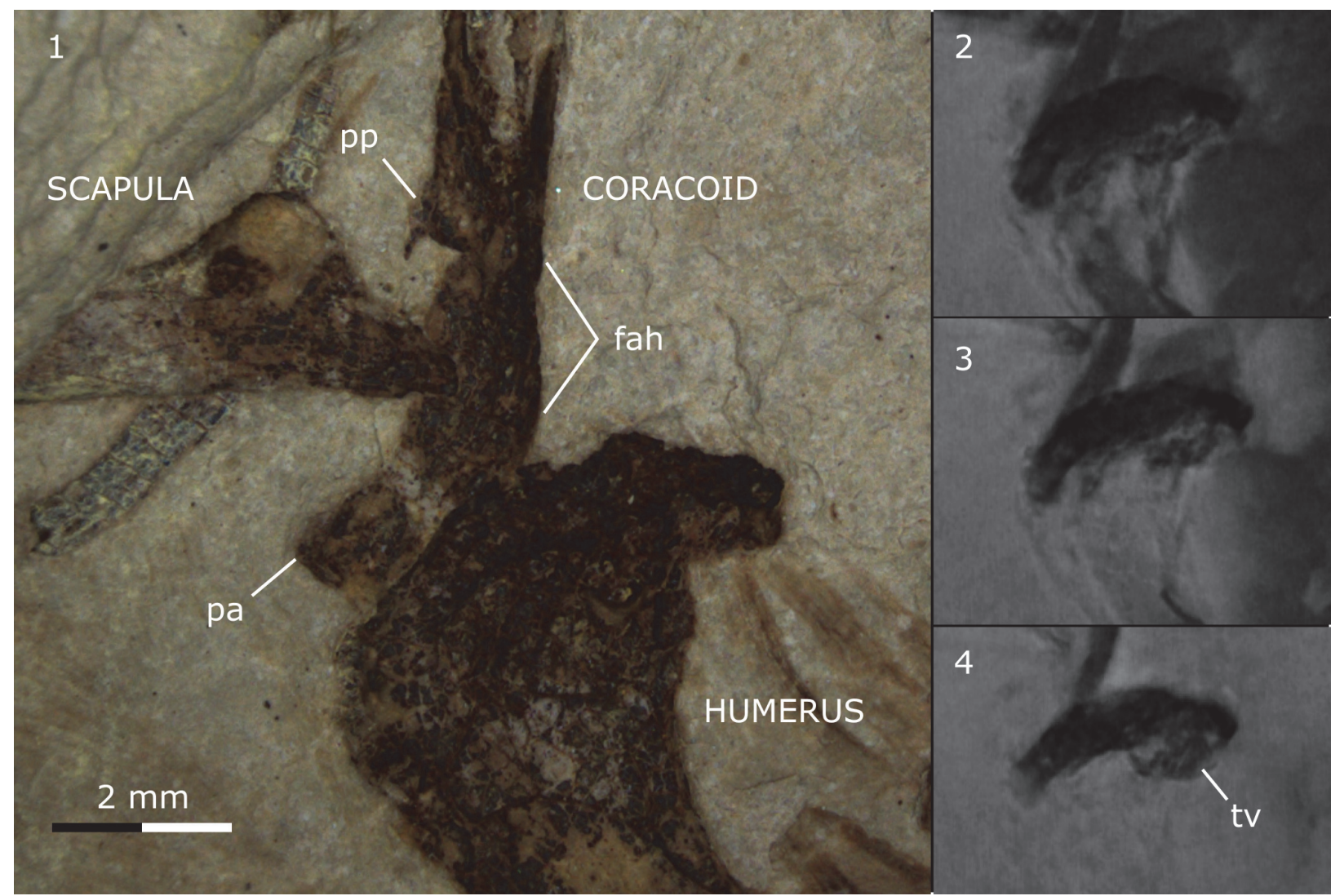

FIGURE 3. Winnicavis gorskii gen. et sp. nov., holotype, specimen ISEA AF/WIN2a+b from Winnica, Poland, early Oligocene. Scapula, coracoid and humerus, main slab. 1- standard photograph, 2 - 4 sequence of CT scans from the slab's surface toward its interior. Abbreviations: fah - facies articularis humeralis, pa - processus acrocoracoideus, $\mathrm{pp}$ - processus procoracoideus, tv - tuberculum ventrale.

extant Acanthisittidae, fossil Primozygodactylus (Mayr, 1998; Mayr and Zelenkov, 2009), Zygodactylus (Mayr, 2008), and two Oligocene passerines Wieslochia weissi and Jamna szybiaki (Mayr and Manegold, 2004, 2006a; Bochenski et al., 2011). As in most Passeriformes, the processus acrocoracoideus itself is elongated; in Coraciiformes it is usually short and stout (Mayr and Mourer-Chauviré, 2000; Mayr et al., 2004; own data). As in Wieslochia and some extant Suboscines (Mayr and Manegold, 2004, 2006a), the processus procoracoideus is somewhat enlarged (Figure 3.1); in extant Acanthisittidae and Oscines it is greatly reduced, whereas in most extinct and extant Coraciiformes it is well-developed, broad and greatly enlarged (Mayr and Mourer-Chauviré, 2000; Mayr et al., 2004; own data). The facies articularis humeralis does not project laterad (Figure 3.1).

Scapula. The relatively wide scapula is embedded with its lateral side in the matrix. The facies articularis humeralis is rounded and stands out from the corpus scapulae. The dorsal margin of the bone is straight.

Humerus. The right humerus is imprinted whole whereas the left is missing its proximal end. Both humeri are embedded with their caudal sides in the matrix. The bone is of similar length to that in extant Parus major. Unlike most extant Passeriformes but similar to the Oligocene Resoviaornis jamrozi and Jamna szybiaki it is very stout, and the proximal epiphysis is wide dorso-ventrally but relatively short. The imprint of the caput humeri is deep, which indicates that the caput humeri was considerably bulging caudally. As in many extant Passeriformes, the Oligocene Wieslochia weissi (Mayr and Manegold, 2004, 2006a) and Resoviaornis jamrozi (Bochenski et al., 2013), the crista deltopectoralis is relatively short and reaches approximately as far distally as the crista bicipitalis; in Jamna szybiaki it is longer and reaches about one-third of the total length of the bone (Bochenski et al., 2011). Unlike both Resoviaornis and Jamna the crista deltopectoralis merges gradually with the shaft. The tuberculum ventrale (better visible in 


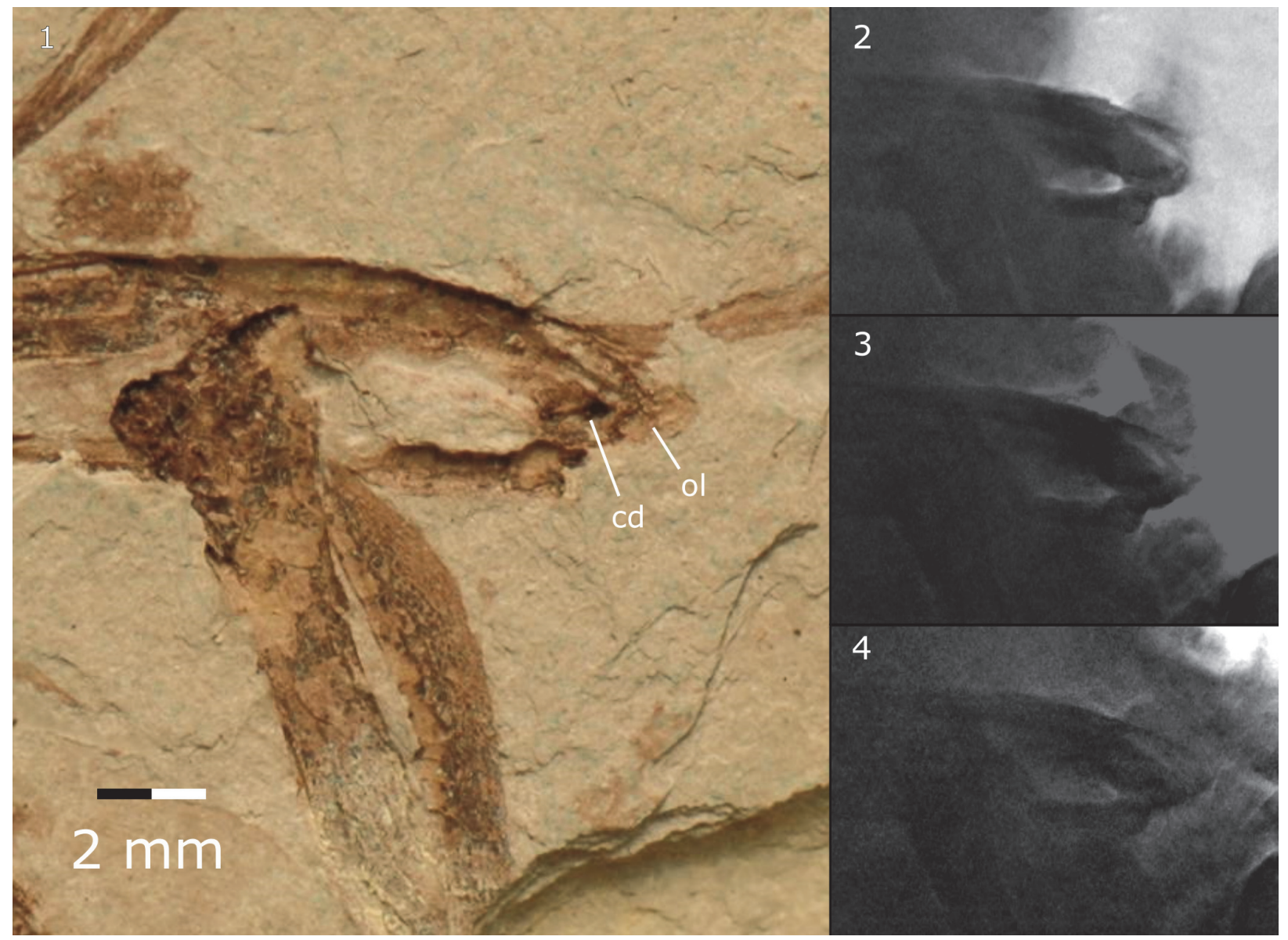

FIGURE 4. Winnicavis gorskii gen. et sp. nov., holotype, specimen ISEA AF/WIN2a+b from Winnica, Poland, early Oligocene. Proximal left ulna and radius, main slab. 1- standard photograph, $2-4$ sequence of CT scans from the slab's surface toward its interior. Abbreviations: cd - cotyla dorsalis, ol - olecranon.

scans) is well marked as in Passeriformes but not as pronounced as in Charadriiformes (Figure 3 ). The fossa pneumotricipitalis is not recognizable even in the scans. The processus supracondylaris dorsalis is not visible either due to its absence or the fact that both distal humeri are superimposed on the ulna and radius. The processus flexorius appears not to protrude far distally as in extant Passeriformes but the condition is not certain due to the superimposed ulna.

Ulna. Both ulnas are embedded with their dorsal sides in the matrix. The bone is long and slender a little longer than the humerus, which agrees with Zygodactylidae (Mayr, 1998; Weidig, 2010) and many Passeriformes including the three known from the Oligocene: Wieslochia, Jamna, and Resoviaornis (Mayr and Manegold, 2004, 2006a; Bochenski et al., 2011, 2013). Under the light microscope the olecranon appears to be short and rounded, but the scans reveal that it projects far proximally, tapers, and its shape resembles that of the extant genus Corvus (Figure 4). In Primozygodactylus and Zygodactylus, the olecranon is short and stout (Mayr, 1998, 2008). As in most Oscines but contrary to Wieslochia, the cotyla dorsalis is proximodistally long, and it protrudes dorsally forming a deep furrow in the matrix. As in many extant Passeriformes and the Oligocene Jamna and Resoviaornis, there is a shallow saddle in the caudal (posterior) margin of the bone between the olecranon and the shaft (better visible on the right bone). The papillae remigiales caudales cannot be discerned which implies that they were either absent or small as in many Passeriformes and Zygodactylidae (Mayr, 1998, 2008; Weidig, 2010), rather than well-pronounced as in many Piciformes.

Carpometacarpus. The complete left carpometacarpus is embedded in the matrix with its dorsal side on the main slab and the ventral side on the counterslab; the right bone is represented by an imprint of its small proximal-most fragment on the 


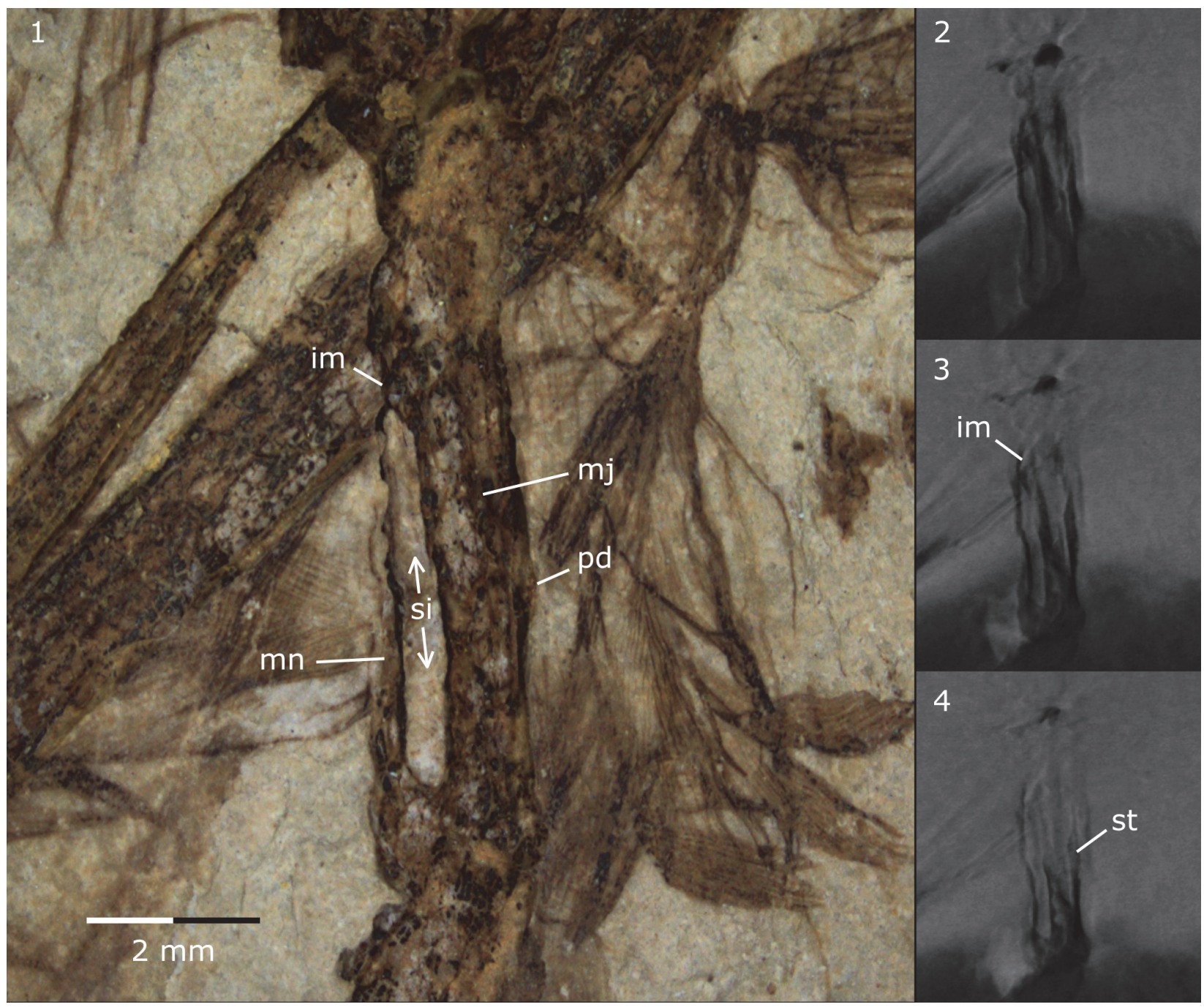

FIGURE 5. Winnicavis gorskii gen. et sp. nov., holotype, specimen ISEA AF/WIN2a+b from Winnica, Poland, early Oligocene. Left carpometacarpus, main slab. 1- standard photograph, 2 - 4 sequence of CT scans from the slab's surface toward its interior. Abbreviations: im - processus intermetacarpalis, mn - os metacarpale minus, mj - os metacarpale majus, pd - processus dentiformis, si - spatium intermetacarpale, st - sulcus tendineus.

main slab. The processus extensorius is slender and points proximally. The spatium intermetacarpale is long and narrow as in many Passeriformes. The processus intermetacarpalis reaches to the os metacarpale minus, which is also documented in the scans of the main slab (Figure 5). Its presence is a derived feature of the passerines (Mayr and Manegold, 2004, 2006a, 2006b); it is also present among others in Piciformes, Zygodactylidae and some Coraciiformes (Mayr, 1998, 2008, 2009; Mayr et al., 2004; Weidig, 2010). The sulcus tendineus (visible in the scans) is deep, straight, and follows the cranial margin of the shaft as in many Passeriformes. An imprint on the cranial margin of the bone (main slab) indicates the pres- ence of the processus dentiformis, which is present in Acanthisittidae and typical for many oscines and suboscines (Pocock, 1966; Mourer-Chauviré et al., 1989; Mayr and Manegold, 2006a, 2006b) but absent in Coraciidae (Mayr, 2006). The distal end of the os metacarpale minus protrudes only a little farther distally than the os metacarpale majus, which resembles the condition in Zygodactylidae, extant Suboscines, early Oligocene Wieslochia weissi and several unassociated carpometacarpi of suboscine affinities from Germany (Mourer-Chauviré et al., 1989; Millener and Worthy, 1991, figure 12; Mayr and Manegold, 2004, 2006a, 2006b; Manegold, 2008). In extant Oscines and the Oligocene Jamna szybiaki and Resoviaornis jamrozi the 


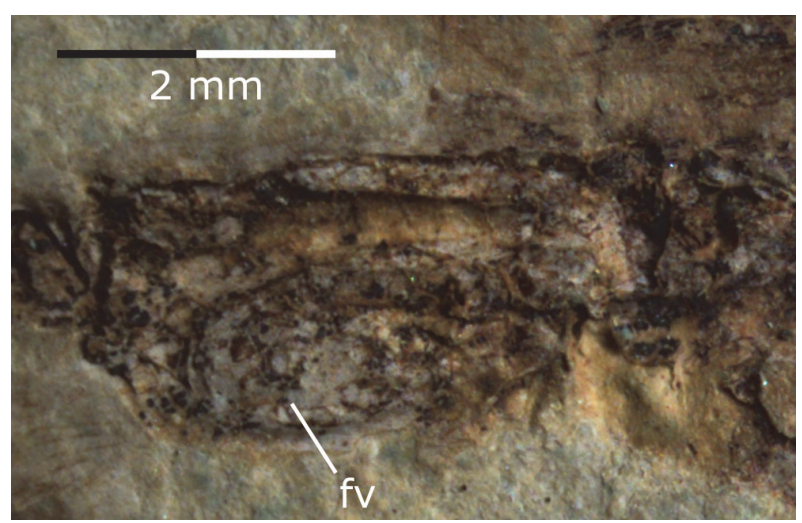

FIGURE 6. Winnicavis gorskii gen. et sp. nov., holotype, specimen ISEA AF/WIN2a+b from Winnica, Poland, early Oligocene. Phalanx proximalis digiti majoris, counterslab. Abbreviation: $\mathrm{fv}$ - fossa ventralis.

distal end of the os metacarpale minus is square and protrudes farther distally, in Coraciiformes the condition varies depending on the group (Mayr et al., 2004). The ventral surface of the synostosis metacarpalis distalis bears a shallow fossa (visible in the counterslab as a small bulging). The condition is in a way similar to that of most extant Oscines and the Oligocene Jamna szybiaki and Resoviaornis jamrozi that show a similar but usually deeper fossa (Mourer-Chauviré et al., 1989; Manegold, 2008; Bochenski et al., 2011, 2013). Only a few Suboscines bear a similar fossa, which can be best explained as convergence (Manegold, 2008).

Other elements of the wing. The phalanx proximalis digiti majoris is embedded with its ventral side in the matrix. It is cleaver-shaped and widens considerably cranio-caudally towards its distal end (Figure 6), which resembles the condition in Suboscines and an Oligocene suboscine-like passerine SMF Av 504 (Mayr and Manegold, 2006b); in Acanthisittidae, Oscines, and the Oligocene Resoviaornis jamrozi this phalanx is approximately of constant width (Bochenski et al., 2013) whereas in Jamna szybiaki it widens only a little cranio-caudally (Bochenski et al., 2011). As in Passeriformes, there is a clear fossa ventralis (visible as a bulging in the counterslab) in this phalanx, and the distal end does not bear any tubercles or projections. As in extant Passeriformes, Jamna szybiaki and Resoviaornis jamrozi, the phalanx distalis digiti majoris is clearly shorter than the phalanx proximalis; in the suboscines-like SMF Av 504 the two phalanges were equal in length (Mayr and Manegold, 2006b).

Proportions. The ratio of humerus length to ulna length (0.78) is similar to that in Resoviaornis jamrozi (0.73) and Wieslochia weissi (0.74) on the one hand, and some extant passerines (e.g., Motacilla alba - 0.76) on the other (Mayr and Manegold, 2004, 2006a; Bochenski et al., 2013; our own data). Jamna szybiaki and all species of the Zygodactylidae have relatively shorter ulna and therefore their brachial index is somewhat larger (0.880.96 ) (Table 1). The carpometacarpus is proportionally shorter (in relation to the humerus and/or ulna) than in most extant or extinct passerines.

Feathers. Multiple feather imprints are visible on both slabs (Figure 2) but none of the imprints

TABLE 1. Measurements (in millimeters) of Winnicavis gorskii gen. et sp. nov., holotype, specimen ISEA AF/WIN2a+b from Winnica, Poland, early Oligocene compared with those of all Oligocene passerine and zygodactylid birds. Abbreviations: cmc - carpometacarpus, hum - humerus. Letters in superscript indicate publications that were checked for measurements. a - Bochenski et al. (2011); b - Bochenski et al. (2013); c - Mayr and Manegold (2004); d - Mayr and Manegold (2006a); e - Weidig (2010); f - Mayr (1998). Asterisk (*) indicates arithmetic mean of left and right bone.

\begin{tabular}{|c|c|c|c|c|c|c|}
\hline Species & Number & hum & ulna & cmc & hum/ulna & hum/cmc \\
\hline Winnicavis gorskii gen. et sp. nov. & ISEA AF/WIN2a+b & 18.6 & $24.0^{*}$ & 9.4 & 0.78 & 1.98 \\
\hline Jamna szybiakia & MSMD Av JAM-6 & $17.2^{*}$ & $18.5^{\star}$ & $9.4^{*}$ & 0.93 & 1.83 \\
\hline Resoviaornis jamrozib & MSMD Av WR-9a+b & $12.4^{*}$ & 17.0 & 8.0 & 0.73 & 1.55 \\
\hline Wieslochia weissic,d & SMF Av 497 & 18.1 & - & 13.2 & - & 1.37 \\
\hline Wieslochia weissid & SMNK-PAL 3980 & 17.7 & 23.8 & 13.4 & 0.74 & 1.32 \\
\hline Eozygodactylus americanuse & USNM 299821 & 16.8 & 19.0 & 8.8 & 0.88 & 1.91 \\
\hline Eozygodactylus americanus ${ }^{\mathrm{e}}$ & WDC-CGR-014 & 17.2 & 18.2 & 8.8 & 0.95 & 1.95 \\
\hline Primozygodactylus danielsif & SMF-ME 2522 (holotype) & 16.5 & 18.3 & 8.2 & 0.90 & 2.01 \\
\hline Primozygodactylus major & SMF-ME 1758 & 28.4 & 31.1 & 12.0 & 0.91 & 2.37 \\
\hline Primozygodactylus ballmannif & SMF-ME 2108 & 21.0 & 22.9 & 9.0 & 0.92 & 2.33 \\
\hline Primozygodactylus ballmannif & HLMD-Me 15396 & 20.0 & 20.9 & 9.1 & 0.96 & 2.20 \\
\hline
\end{tabular}


shows a complete feather, and the feathers superimpose on one another, which further hampers observations. Vanes with distinct barbs can be recognized in many feathers. Fragments of at least 12 flight feathers from the right wing can be distinguished on the counterslab. They appear to represent both primaries (1) and secondaries (2). At least a dozen small contour feathers are visible on both slabs. Those near the distal half of the left ulna (main slab) are probably underwing coverts (3), two feathers of more compact structure near the right ulna (main slab) are probably primary coverts (4). Other feathers are unidentifiable.

\section{DISCUSSION}

As in all other passerine birds described so far from the Oligocene (Wieslochia weissi, Jamna szybiaki, Resoviaornis jamrozi), the exact systematic position of Winnicavis gorskii is also a scientific challenge. Morphological characters indicate that it belongs in Passeriformes, but its more precise affinities remain obscure. We are even unsure whether to classify it within Oscines or Suboscines because the specimen shows a mosaic of characters typical for one or the other taxonomic group. This feature, together with the fact that all Oligocene avian specimens clearly differ from one another in many characters (Mayr and Manegold, 2004, 2006a; Bochenski et al., 2011, 2013, 2014a, $2014 b)$, points to a great diversity among early passerines in Europe. One of the rather few common features among them is the small size (Mayr and Manegold, 2006a; Manegold, 2008; Mayr, 2009), which is confirmed by Winnicavis gorskii.

The flight mode in birds is strictly connected with the wing morphology that includes feathers and bones (Norberg, 1979; Bochenski and Bochenski, 1992; Nudds et al., 2004, 2007; Nudds, 2007; Simons, 2010; Wang et al., 2011). Although we do not know anything about the flight feathers of Winnicavis gorskii, we can deduce from the humerus to ulna ratio that it likely represented the "passerine-type flight", which is characterized by flapping phases and pauses, as opposed to continuous flapping, flapping and soaring, and flapping and gliding (Bruderer et al., 2010; Wang et al., 2011). The length of avian manus (carpometacarpus + phalanx proximalis digiti majoris + phalanx distalis digiti majoris), of which the carpometacarpus is the main bone, is not correlated with distinct patterns of wing movements; its relative length can be almost identical in various kinematic avian groups (Nudds et al., 2007; Wang et al., 2011). Therefore, we may assume that the relatively short carpometacarpus in Winnicavis gorskii did not necessarily influence its flight style; its small size could have been compensated for by the primaries, which seems to take place among extant tits (Norberg, 1979).

Despite its limitations, micro-computed tomography proved to be useful because it enabled us to see fossilized bone remains hidden beneath the surface of the matrix. Some of the observed features are important in the diagnostics of the specimen (e.g., the well-developed tuberculum ventrale, or the shape of the olecranon). We postulate to use the method on a more regular basis, especially when the specimens are very fragile and therefore difficult to prepare and/or transfer to a resin matrix.

The preserved skeletal elements of Winnicavis gorskii are articulated with one another and disarticulated from bones that are missing. This suggests that the carcass reached the bottom of the ocean shortly after death, where it was buried in the sediments in a quiet anoxic environment without underwater turbulences that would stimulate its disarticulation (Bienkowska-Wasiluk, 2010). In this respect it resembles all other Oligocene birds and most fishes described so far from the Carpathians (Kotlarczyk et al., 2006; Bochenski and Bochenski, 2008; Bochenski et al., 2010, 2011, 2013, 2014a, 2014b; Tomek et al., 2014; Mayr and Bochenski, 2016).

\section{REFERENCES}

Baumel, J.J. and Witmer, L.M. 1993. Osteologia, p. 45-132. In Baumel, J.J., King, A.S., Breazile, J.E., Evans, H.E., and Vanden Berge, J.C. (eds.), Handbook of Avian Anatomy: Nomina Anatomica Avium. Publications of the Nuttall Ornithological Club, No 23. Nuttall Ornithological Club, Cambridge, Massachusetts.

Berggren, W.A., Kent, D.V., Swisher, C.C., and Aubry, M.-P. 1995. A revised Cenozoic geochronology and chronostratigraphy, p. 129-212. In Berggren, W.A., Kent, D.V., Aubry, M.P., and Hardenbol, J. (eds.), Geochronology, Time Scales and Global Stratigraphic 
Correlation. Special Publication - SEPM (Society for Sedimentary Geology), No. 54. SEPM Society for Sedimentary Geology, Tulsa, Oklahoma. https://doi.org/10.2110/pec.95.04.0129

Bienkowska-Wasiluk, M. 2010. Taphonomy of Oligocene teleost fishes from the Outer Carpathians of Poland. Acta Geologica Polonica, 60:479-533.

Bochenski, Z. and Bochenski, Z.M. 1992. Correlation between the wing length of living birds and measurements of their bones. Belgian Journal of Zoology, 122:123-132.

Bochenski, Z. and Bochenski, Z.M. 2008. An Old World hummingbird from the Oligocene: a new fossil from Polish Carpathians. Journal of Ornithology, 149:211-216. https://doi.org/10.1007/ s10336-007-0261-y

Bochenski, Z.M., Tomek, T., Bujoczek, M., and Wertz, K. 2011. A new passerine bird from the early Oligocene of Poland. Journal of Ornithology, 152:1045-1053. https://doi.org/10.1007/ s10336-011-0693-2

Bochenski, Z.M., Tomek, T., and Swidnicka, E. 2010. A columbid-like avian foot from the Oligocene of Poland. Acta Ornithologica, 45:233-236. https://doi.org/10.3161/ $000164510 \times 551363$

Bochenski, Z.M., Tomek, T., and Swidnicka, E. 2014a. The first complete leg of a passerine bird from the early Oligocene of Poland. Acta Palaeontologica Polonica, 59:281-285. https:// doi.org/10.4202/app.2012.0021

Bochenski, Z.M., Tomek, T., and Swidnicka, E. 2014b. A complete passerine foot from the late Oligocene of Poland. Palaeontologia Electronica 17.1.6A:7p. https://doi.org/10.26879/431 palaeo-electronica.org/content/2014/674-oligocene-passerine-foot

Bochenski, Z.M., Tomek, T., Wertz, K., and Swidnicka, E. 2013. The third nearly complete passerine bird from the early Oligocene of Europe. Journal of Ornithology, 154:923-931. https://doi.org/10.1007/s10336-013-0958-z

Boles, W.E. 1995. The world's oldest songbird. Nature, 374:21-22. https://doi.org/10.1038/ $374021 \mathrm{b0}$

Boles, W.E. 1997. Fossil songbirds (Passeriformes) from the early Eocene of Australia. Emu, 97:43-50. https://doi.org/10.1071/MU97004

Bruderer, B., Peter, D., Boldt, A., and Liechti, F. 2010. Wing-beat characteristics of birds recorded with tracking radar and cine camera. Ibis, 152:272-291. https://doi.org/10.1111/ j.1474-919x.2010.01014.x

Ericson, P.G.P., Christidis, L., Cooper, A., Irestedt, M., Jackson, J., Johansson, U.S., and Norman, J.A. 2002. A Gondwanan origin of passerine birds supported by DNA sequences of the endemic New Zealand wrens. Proceedings of the Royal Society B, 269:235-241. https:// doi.org/10.1098/rspb.2001.1877

Heckel, J.J. 1856. Beiträge zur Kenntnis der fossilen Fische erreichs. Denkschriften der kaiserlischen Akademie der Wissenschaften Mathematisch-Naturwissenschaftliche Classe, 11:187-274.

Kotlarczyk, J., Jerzmańska, A., Świdnicka, E., and Wiszniowska, T. 2006. A framework of ichthyofaunal ecostratigraphy of the Oligocene-Early Miocene strata of the Polish Outer Carpathian basin. Annales Societatis Geologorum Poloniae, 76:1-111.

Linnaeus, C. 1758. Systema Naturae, per regna tria naturae, secundum Classes, Ordines, Genera, Species, cum characteribus, differentiis, synonymis, locis, 10th edn. Laurentius Salvius, Stockholm.

Manegold, A. 2008. Passerine diversity in the late Oligocene of Germany: earliest evidence for the sympatric coexistence of Suboscines and Oscines. Ibis, 150:377-387. https://doi.org/ 10.1111/j.1474-919x.2008.00802.x

Martini, E. 1971. Standard Tertiary and Quaternary calcareous nannoplankton zonation, p. 739785. In Farrinacci, A. (ed.), Proceedings of the II Planktonic Conference, Roma, 1970: Volume 2. Edizioni Tectoscienza, Rome.

Mayr, G. 1998. "Coraciiforme" und "piciforme" Kleinvögel aus dem Mittel-Eozän der Grube Messel (Hessen, Deutschland). Courier Forschungsinstitut Senckenberg, 205:1-101.

Mayr, G. 2006. New specimens of the Eocene Messelirrisoridae (Aves: Bucerotes), with comments on the preservation of uropygial gland waxes in fossil birds from Messel and the phylogenetic affinities of Bucerotes. Paläontologische Zeitschrift, 80:390-405. https://doi.org/ 10.1007/BF02990211

Mayr, G. 2008. Phylogenetic affinities of the enigmatic avian taxon zygodactylus based on new material from the early Oligocene of France. Journal of Systematic Palaeontology, 6:333344. https://doi.org/10.1017/S1477201907002398 
Mayr, G. 2009. Paleogene Fossil Birds. Springer, Berlin.

Mayr, G. 2013. The age of the crown group of passerine birds and its evolutionary significancemolecular calibrations versus the fossil record. Systematics and Biodiversity, 11:7-13. https:/ /doi.org/10.1080/14772000.2013.765521

Mayr, G. and Bochenski, Z.M. 2016. A skeleton of a small rail from the Rupelian of Poland adds to the diversity of early Oligocene Ralloidea. Neues Jahrbuch für Geologie und Paläontologie-Abhandlungen, 282:125-134. https://doi.org/10.1127/njgpa/2016/0609

Mayr, G. and Manegold, A. 2004. The oldest European fossil songbird from the early Oligocene of Germany. Naturwissenschaften, 91:173-177. https://doi.org/10.1007/s00114-004-0509-9

Mayr, G. and Manegold, A. 2006a. New specimens of the earliest European passeriform bird. Acta Palaeontologica Polonica, 51:315-323.

Mayr, G. and Manegold, A. 2006b. A small suboscine-like passeriform bird from the early Oligocene of France. Condor, 108:717-720. https://doi.org/10.1650/00105422(2006)108[717:asspbf]2.0.co;2

Mayr, G. and Mourer-Chauviré, C. 2000. Rollers (Aves: Coraciiformes s.s.) from the middle Eocene of Messel (Germany) and the upper Eocene of the Quercy (France). Journal of Vertebrate Paleontology, 20:533-546. https://doi.org/10.1671/02724634(2000)020[0533:RACSSF]2.0.CO;2

Mayr, G., Mourer-Chauviré, C., and Weidig, I. 2004. Osteology and systematic position of the Eocene Primobucconidae (Aves, Coraciiformes sensu stricto), with first records from Europe. Journal of Systematic Palaeontology, 2:1-12. https://doi.org/10.1017/S1477201903001093

Mayr, G. and Zelenkov, N. 2009. New specimens of zygodactylid birds from the middle Eocene of Messel, with description of a new species of Primozygodactylus. Acta Palaeontologica Polonica, 54:15-20. https://doi.org/10.4202/app.2009.b103

Millener, P.R. and Worthy, T.H. 1991. Contributions to New Zealand's Late Quaternary avifauna. II: Dendroscansor decurvirostris, a new genus and species of wren (Aves: Acanthisittidae). Journal of the Royal Society of New Zealand, 21:179-200. https://doi.org/10.1080/ 03036758.1991.10431406

Mourer-Chauviré, C. 2006. The avifauna of the Eocene and Oligocene Phosphorites du Quercy (France): an updated list. Strata Série 1, 13:135-149.

Mourer-Chauviré, C., Berthet, D., and Hugueny, M. 2004. The late Oligocene birds of the Créchy quarry (Allier, France), with a description of two new genera (Aves: Pelecaniformes: Phalacrocoracidae, and Anseriformes: Anseranatidae). Senckenbergiana lethaea, 84:303-315. https://doi.org/10.1007/BF03043473

Mourer-Chauviré, C., Hugueney, M., and Jonet, P. 1989. Découverte de Passeriformes dans l'Oligocène supérieur de France. Comptes Rendus de l'Académie des Sciences - Série 2, 309:843-849.

Norberg, U.M. 1979. Morphology of the wings, legs and tail of three coniferous forest tits, the goldcrest, and the treecreeper in relation to locomotor pattern and feeding station selection. Philosophical Transactions of the Royal Society of London B: Biological Sciences, 287:131-165. https://doi.org/10.1098/rstb.1979.0054

Nudds, R.L. 2007. Wing-bone length allometry in birds. Journal of Avian Biology, 38:515-519. https://doi.org/10.1111/j.0908-8857.2007.03913.x

Nudds, R.L., Dyke, G.J., and Rayner, J.M.V. 2004. Forelimb proportions and the evolutionary radiation of Neornithes. Proceedings of the Royal Society of London B: Biological Sciences, 271(Suppl. 5):S324-S327. https://doi.org/10.1098/rsbl.2004.0167

Nudds, R.L., Dyke, G.J., and Rayner, J.M.V. 2007. Avian brachial index and wing kinematics: putting movement back into bones. Journal of Zoology, 272:218-226. https://doi.org/10.1111/ j.1469-7998.2006.00261.x

Paucă, M. 1929. Vorläufige Mitteilung über eine fossile Fischfauna aus den Oligozänschiefern von Suslaneşti (Muscel). Bulletin de l'Academie Roumaine, Section Scientifique, 12(4/ 5):112-124.

Pocock, T.N. 1966. Contributions to the osteology of African birds. Ostrich, 37(sup1):83-94. https://doi.org/10.1080/00306525.1966.9639791

Simionescu, I. 1905. Sur quelques poissons fossiles du tertiaire roumain. Annales Scientifiques de l'Université de Jassy, 5:1-17.

Simons, E.L. 2010. Forelimb skeletal morphology and flight mode evolution in pelecaniform birds. Zoology, 113:39-46. https://doi.org/10.1016/j.zool.2009.05.002 
Tomek, T., Bochenski, Z.M., Wertz, K., and Swidnicka, E. 2014. A new genus and species of a galliform bird from the Oligocene of Poland. Palaeontologia Electronica 17.3.38A:14p. https:/ /doi.org/10.26879/474 palaeo-electronica.org/content/2014/933-galliform-bird-from-oligocene

Wang, X., McGowan, A.J., and Dyke, G.J. 2011. Avian wing proportions and flight styles: first step towards predicting the flight modes of Mesozoic birds. PLoS One, 6(12):e28672. https:// doi.org/10.1371/journal.pone.0028672

Weidig, I. 2010. New birds from the Lower Eocene Green River Formation, North America. Records of the Australian Museum, 62:29-44. https://doi.org/10.3853/j.00671975.62.2010.1544 